\title{
Cooking the Books: Bureaucratic Politicization and Policy Knowledge
}

\author{
Frida Boräng, University of Gothenburg \\ Agnes Cornell, Aarhus University \\ Marcia Grimes, University of Gothenburg \\ Christian Schuster, University College London
}

\begin{abstract}
Scholars have become increasingly aware of the extent and mechanisms through which various aspects of state capacity affect the functioning of democracy. Weak state capacity, in particular, has been linked to public goods delivery failures, corruption and clientelistic electoral strategies. This paper adds to this line of investigation by positing and testing a distinct mechanism through which one aspect of state capacity - bureaucratic politicization affects the functioning of democracy: by facilitating the politicization of public policy data produced by governments. A politicized bureaucracy enhances the ability of politicians to demand from bureaucrats - and raises incentives for bureaucrats to supply - public policy knowledge that is strategically biased or suppressed in a manner which benefits the incumbent. A case analysis of Argentina's statistical agency and time-series cross-section analysis provide evidence. Politicized bureaucracies enable incumbents to both court voters with private goods and deprive voters of knowledge to judge governments by their public goods performance.
\end{abstract}

Forthcoming in Governance 
Deputy Commissioner Rawls: Felony rates will decline by 5 percent by the end of the year.

Police Commissioner Burl: ... in addition, we will hold this year's murders to 275, or less.

District Major Colvin: Ah, Deputy, as familiar as we all are with the urban crime environment, I think we all understand there are certain ... um...uh...processes by which you can ...uh...reduce the number of overall felonies. You can reclassify an agg assault ${ }^{1}$ or you can unfound a robbery, but...um... how do you make a body disappear?

Police Commissioner Burl: There isn't one of you in this room who isn't here by appointment. If you want to continue wearing those oak leaf clusters ${ }^{2}$ you will shut up and step up. Any of you who can't bring the numbers we need will be replaced by someone who can (The Wire, season 3).

\section{Introduction}

Accurate knowledge about societal conditions and the effects of public policies is an important public good in any polity. Such knowledge is essential to the formulation of evidence-based policy that responds appropriately to socio-economic needs, as well as to sounder investment decisions by businesses (Krätke and Byiers 2014; Williams 2010). Equally importantly, timely and reliable information on societal conditions is "one of the foundations of democratic dialogue” (Mulgan, 2007, p. 584). Open policy debates and electoral accountability presuppose the existence and availability of accurate policy knowledge. Public sector organizations play a crucial role in the production and dissemination of such knowledge, as private agents frequently lack the data access and above all the incentives to produce this nonrivalrous and non-excludable good (Serra 2014).

Yet, governments across the world differ dramatically in the extent to which they compile and make publicly available reliable knowledge about policy, the economy and society. The World Bank's Statistical Capacity Indicator, a score of coverage, periodicity and timeliness of economic statistics produced by governments, finds that country scores range from 20 to 99 on a scale that ranges from 0 to 100 (World Bank 2014). A similar index (discussed in more detail below) that captures the extent to which governments publish reliable key policy-related indicators also reports significant variation across the globe (Hollyer et al. 2014).

While numerous political, institutional and administrative factors invariably contribute to this variation, this paper develops a novel argument to explain the varying extent to which governments produce and publish accurate policy knowledge. We test the argument qualitatively and quantitatively using methods that examine change within countries over time. In doing so, we identify a mechanism previously not discussed in the literature through

\footnotetext{
${ }^{1}$ Aggravated assault.

${ }^{2}$ US Military insignia awarded to holders of certain military decorations to indicate a further distinction.
} 
which one component of the structure of the state - the extent to which politicians have control over civil servants' careers, or bureaucratic politicization - affects government's propensity to produce reliable policy data. Prior studies have linked the politicization of bureaucracy with a number of interrelated syndromes that ail democracy, including corruption, clientelist electoral competition, the inability to make credible electoral public goods promises, and poor public goods provision (Bersch, Praça and Taylor, 2016; Cornell and Grimes 2015a, b; Dahlström, Lapuente, and Teorell 2012; Geddes 1994; Keefer 2007; Nistotskaya and Cingolani, 2015; Shefter 1994; Stokes et al., 2013). We add to this line of investigation by exploring the effect of bureaucratic politicization on policy-making and good government through a separate mechanism: the politicization of policy knowledge.

The quote in the epigraph provides a fictional yet instructive illustration of the argument: the politicization of bureaucratic appointments may induce the politicization of policy knowledge compiled and published by government officials. A politicized bureaucracy enhances the ability of politicians to demand from bureaucrats - and raises incentives for bureaucrats to supply - public policy knowledge that is strategically biased or suppressed in a manner which benefits the incumbent. In other words, politicized bureaucracies enable incumbents not only to court voters with private goods in exchange for electoral support; but also to deprive voters of the requisite knowledge and data to judge government performance by any other means than such private goods receipts. This adds a further rationale for the electoral success of clientelist politician-incumbents politicizing the bureaucracies they oversee - and for the prevalence of bureaucratic politicization in many parts of the world.

The paper unpacks and provides evidence for this argument in four steps. The first section reviews the existing literature and establishes the central role of bureaucrats in the production of (unbiased) policy knowledge. The second section then develops the theoretical argument, specifying the mechanisms through which politicization may bias policy knowledge. Furthermore, it suggests that the relationship is likely to be much stronger in democracies than in autocracies. We then investigate the theoretical claims empirically through a mixed methods approach. A case analysis of the effect of bureaucratic politicization on the production of politicized policy knowledge in Argentina's national statistical agency Indec (Instituto Nacional de Estadística y Censos de la República Argentina) lends credence to the theorized mechanisms which link bureaucratic politicization with politicized policy knowledge in a single (important) case. Subsequently, the theorized causal effect is assessed through large-n time-series cross-country analysis. In the analyses, political control of the 
bureaucracy is negatively associated with the availability of policy knowledge across a range of different specifications. Congruent with the theoretical argument, the relationship is only significant in democracies - not autocracies.

\section{Bureaucrats and the Production of Policy Knowledge}

Often understood as a "justifiable belief," knowledge can come in many forms, be these scientific, practical or local, for instance (Van Kerkhoff and Lebel, 2006, 447). In this paper, we narrow in on one, arguably particularly important form of knowledge in a polity: evaluations and statistics produced by government agencies related to the target conditions and impacts of past policies, or estimates of these with respect to future policies (henceforth: policy knowledge). This includes not only data from policy evaluations but also data about the societal and economic conditions more generally.

Public sector organizations are central in the production of such knowledge, and bureaucrats are the "principal actors in charge of the production of official statistics" (Krätke and Byiers 2014, 28). To gather, compute, compile and report such knowledge is a staple duty in many positions in state agencies. Public officials are "crucial in guaranteeing [the] accuracy" of the public record (Mulgan, 2007, 584). In other words, they do not only "speak truth to power," as Wildavsky (1979) prominently remarked. They also are central to speaking truth to the public.

The notion of truth in statistics is, of course, a contested one (Deborah Stone 2012). All counting requires categorization, that is, whom to include and exclude in a statistic; a decision that a phenomenon is measurable; and a decision to count in the first place, to name a few. The latter is inevitable as collecting and disseminating policy knowledge is costly (Repo 1989).

Discretion in whether, what and how to count and publish does not, however, imply the absence of "a perception of what constitutes 'good data' and 'good statistics"” (Krätke and Byiers, 2014, 29). International guidelines on what and how to count frequently set quality standards for statistics in order to minimize bias and error, and to assure transparency and replicability on what and how to count.

As central "agents of knowledge" production (Diane Stone 2012, 339), bureaucrats potentially play a key role in biasing the coverage and accuracy of policy knowledge as well. Why would 
bureaucrats introduce such biases in the production and/or publication of policy knowledge? To begin with, bureaucrats may lack the ability to produce accurate policy knowledge. In developing countries, for instance, "statistical literacy is still in its infancy even in government circles" (Jerven 2013, 105). Moreover, bureaucrats may face incentives to exaggerate statistics that measure their own performance, which may be tied to funding allocations. As Wildavsky $(1979,236)$ put it, "[ $[\mathrm{t}]$ he desire to pass on only good news eliminates information that might put the conveyer in a bad light." This type of conflict of interest is prevalent: "line ministries require [self-reported] data on thousands of schools, clinics, police stations, water points, and road maintenance activities across the country" (Sandefur and Glassman 2014, 16). Gaming in self-reported performance data is thus frequent (Hood, 2006). Bureaucrats may also face incentives to self-censor. In the UK, for example, Stevens (2011) showcases how career concerns incentivize bureaucrats to downplay methodological uncertainty underlying policy choices and suppress evidence about policy failures.

Note, however, that the existing literature has principally focused on bureaucrats facing incentives to bias policy knowledge to favour their own careers and agencies. These studies have, however, not sought to understand why the availability of policy knowledge would vary sharply across countries (cf. Hollyer, Rosendorff and Vreeland, 2011; World Bank, 2014). The next section develops a novel, institutional argument to account for this variation.

\section{Politicized Bureaucracies and Biased Policy Knowledge}

In view of the centrality of unbiased policy knowledge, exploring the institutional factors that incentivize the production of biased policy knowledge is warranted. In this paper, we focus on one crucial institutional determinant: bureaucratic politicization, defined as the degree to which politicians control bureaucratic careers (Dahlström, Lapuente, and Teorell 2012; Evans and Rauch 1999; Geddes 1994; Wood and Waterman 1991). A politicized bureaucracy is thus a bureaucracy in which employees are recruited, promoted and dismissed principally on political grounds as opposed to on merit and professional skills.

The identification of bureaucratic politicization as a key source of biased policy knowledge draws on insights from two separate strands of prior research. First, scholars studying developing states, in particular, have shed light on the extent and mechanisms through which bureaucratic politicization affects the functioning of government, including the prevalence of clientelist electoral strategies, corruption, service delivery failures and lower democratic 
stability (see, among many, Cingolani, Thomsson, and de Crombrugghe 2015; Cornell and Grimes 2015a, b; Cornell and Lapuente 2014; Dahlström and Lapuente, forthcoming; Dahlström, Lapuente, and Teorell 2012). These scholars have, however, yet to explore the implications of political control of the bureaucracy for policy knowledge.

As such, it also engages with a second, distinct literature on the politicization of policy advice in developed Westminster systems (Aucoin, 2012; Grube, 2014; Mulgan, 2007). The concurrent rise of media management, freedom of information regimes, performance audits, political competition and political polarization are argued to have led to a "New Political Governance" (NPG) in these countries (Aucoin, 2012, 178). NPG is characterized by permanent executive campaigning, greater weight of partisan-political staff, senior civil service politicization and promiscuous partisanship by civil servants - including in regards to policy advice. One hypothesized determinant of the extent of policy advice politicization is the independence of senior public service staffing. Where such independent staffing is lacking, the impartiality of public servants is threatened - including in regards to their policy advice (see Aucoin, 2012; Mulgan, 2007).

We build on these insights and argue that bureaucratic politicization will, analogously, shape the incentives and ability of bureaucrats to supply - and politicians to demand from bureaucrats - unbiased policy knowledge. We go further than the NPG literature, however, by clearly specifying the underlying causal mechanisms and extending the argument to both developed and developing economies rather than only NPG Westminster systems. Contrary to "NPG countries" where the extent of bureaucratic politicization is both contested and limited (Boston and Nethercote, 2012), developing countries feature to a greater, yet varying, extent politicized bureaucracies (Dahlström et al., 2015). As such, examining this relationship in developed and developing economies provides for, arguably, the more relevant setting to theorize and examine the relationship between bureaucratic politicization and the politicization of policy knowledge.

With this in mind, this paper posits four mechanisms to account for how bureaucratic politicization affects the ability and incentives of bureaucracies to produce and publish reliable policy knowledge: (1) incentives to bias statistics upwards or suppress unflattering statistics to keep their political patrons - and thus themselves - in office (re-election incentive); (2) bureaucrats' fear of career punishment when resisting political pressure for biased knowledge (punishment incentive); (3) lower propensity to whistle-blow in response to false performance 
claims or unfeasible pledges of future policy endeavors (reputational incentive); and (4) bureaucratic capacity to produce reliable policy knowledge (capacity). ${ }^{3}$

First, in democratic states that also have politicized bureaucracies, the logic of electoral cycles incentivizes civil servants to suppress or bias policy knowledge since their own career fates are tied to the electoral fates of their political patrons (see Oliveros 2013; Robinson and Verdier 2013 for analogous arguments about patronage contracts and public service delivery). In bureaucracies in which recruitment and dismissal are politicized, the continued employment of bureaucrats is contingent upon their party winning the next election, giving them a strong incentive to join politicians' efforts to secure the necessary votes. Politically appointed bureaucrats thus face greater incentives to overstate the incumbent's accomplishments in order to strengthen the chances of reelection, and conversely to disregard information that could undermine the incumbent's electoral prospects. In democracies, in other words, bureaucratic politicization conflates the incentive structures of politicians and bureaucrats, introducing the pressures of the electoral cycle not only into the accomplishments of government agencies, but also into the empirical description of those accomplishments.

Three additional mechanisms may, theoretically, lead to the distortion of policy data in both democracies and autocracies. While the first mechanism pointed to the fact that politicization may induce civil servants to bias statistics in a willing and complicit manner, bureaucrats as political appointees may also doctor numbers simply because of political pressure. Where politicization of appointment coincides with politicization of promotions and dismissal (c.f. Schuster 2016), bureaucratic job stability and career prospects are at the discretion of political incumbents. When bureaucrats are dependent on politicians for continued employment and career progression, the ability of politicians to pressure bureaucrats into suppressing unfavorable reports, or even producing and releasing biased policy knowledge is greatly enhanced. Fear of punishment may also intensify the inclination for bureaucrats to self-censor. Disclosing sobering information about the current state of affairs, or about the ineffectiveness of politicians' policy programs, could entail personal career costs for bureaucrats, resulting in skewed evaluation and reporting.

\footnotetext{
${ }^{3}$ To clarify, we do not claim that bureaucracies were politicized exclusively or even primarily to allow incumbents to manipulate or suppress policy knowledge relevant to evaluating government performance; the institutional arrangements that afford politicians the ability to control bureaucracies may have come about for a range of reasons (see Schuster, 2016a for a review of these causes).
} 
Third, bureaucrats in politicized bureaucracies are less likely to face reputational incentives to resist the biasing policy knowledge. By contrast, in professional bureaucracies career incentives which reward professional expertise and a stronger professional ethos tend to foster speaking truth to the public. A professional esprit de corps may enhance bureaucratic dispositions to act as whistle blowers to the public when politicians seek to distort the collection or disclosure of official statistics. Professional bureaucrats also face additional career incentives to speak truth to the public about their agencies. Biasing official statistics to overstate the accomplishments of incumbents may benefit executives but are likely to undermine an agency's prestige in the long-run, which may affect career prospects outside the agency. In sum, in statistics offices, "professional bureaucrats ... want to avoid reputational risks, partly in order to retain their current position as well as chances of finding gainful employment elsewhere as professional statisticians” (Krätke and Byiers 2014, 6).

Lastly, bureaucratic politicization may reduce bureaucratic capacity, which in turn impairs the coverage and accuracy of policy knowledge (Krause, Lewis and Douglas, 2006). According to Krätke and Byiers $(2014,6)$, for instance, "lack of technical skills (most critically in national statistics offices) are often ... the reason for poor (i.e. incomplete, low-quality) statistics." Political appointees in general have fewer relevant skills when hired as political criteria typically take precedence over merit in appointments (Gallo and Lewis 2011; Lewis 2007), and also have weaker incentives to develop their own expertise in agencies where turnover is high, which is likely to be greater in politicized bureaucracies (Gailmard and Patty 2007; but see Schuster 2016a). This creates a situation in which the bureaucracy is composed to a larger extent of inexperienced officials and in which organizational and policy knowledge fails to accumulate (Cornell 2014).

In sum, bureaucratic politicization may incentivize bias or suppression of policy knowledge in a polity through four different mechanisms. We expect the relationship between bureaucratic politicization and the politicization of policy knowledge to be stronger in democracies than autocracies. The rationale for this has two bases. First, that bureaucrats willingly cook the books to favor incumbents (the re-election mechanism) is in all likelihood primarily at work in democracies, and moreover, the production of policy knowledge is more relevant in democracies since democratic rulers rely on support from a majority of the population. Second, autocrats presumably also have other tools at their disposal to control information. They may, for example, control the flow of information in the media. Thus, even 
though autocrats do politicize bureaucracies at higher levels than democracies ${ }^{4}$ and are more restrictive with respect to the publication and circulation of policy data (Hollyer, Rosendorff and Vreeland 2011), we do not expect politicization to be a major tool for controlling the production of policy knowledge in autocracies.

We assess our argument empirically in two steps. First, we draw on a case study of Argentina's statistical agency to assess the theorized mechanisms linking bureaucratic politicization with biased official statistics. The Argentinian case points to the validity of the mechanisms underlying our argument, and their importance in democracies in particular, with an electoral logic driving attempts to politicize the bureaucracy and manipulate statistics. Subsequently, we assess the generality of the causal effect employing time-series cross-section analysis in democracies and autocracies.

\section{Cooking the Books: politicizing policy knowledge in Argentina}

Argentina's statistical agency Indec (Instituto Nacional de Estadística y Censos) serves as a contemporary and insightful case to assess and shed light on the theorized mechanisms linking political control of the bureaucracy with biased policy data. The case selection rationale is two-fold. First, the case offers longitudinal variation in our focal relationship, the effect of politicization on the production of policy knowledge, within a single agency. This offers the advantage of holding constant many other institutional and political factors which could, in cross-country or cross-institutional analyses, act as confounders. Rather than seeking to provide a holistic understanding of these factors in the case of Indec, the case analysis thus focuses on tracing the specific process of the effect of bureaucratic politicization in 2007 on the production of policy knowledge (cf. Eckstein, 1975; George and Bennett, 2005; Yin, 2013).

Second, Indec's politicization has been highly contested and publicized in the media and provoked several judicial investigations (see, for instance, La Nación 2015; The Economist 2013; Ministerio Público de la Nación 2007a). The degree of publicness of these events contrasts with the covert politics typically surrounding the politicization of policy knowledge

\footnotetext{
${ }^{4}$ Autocracies evince higher levels of bureaucratic politicization, though considerable variation exists in both regime types. The measure of bureaucratic impartiality, a proxy measure for bureaucratic politicization used in the analyses below, ranges from -2.03 to 3.78 in the sample for 2010. The mean (and standard deviation) for 2010 are $1.28(1.37)$ and $-0.34(.85)$ for democracies and non-democracies respectively.
} 
- which is by definition challenging to shed empirical light on. This makes the Argentinian case empirically exceptional and results in a well-documented analysis based on judicial, media and international organization reports. The analysis substantiates the causal claims put forth: the politicization of bureaucratic appointments, promotions and tenure in Indec contributed to biasing the production of statistics in favor of incumbent performance through the theorized mechanisms.

Prior to its 2007 politicization, Indec featured a partially professionalized bureaucracy. The agency was created in 1968 as an administrative dependency of the Ministry of the Economy and Production, albeit with functional independence for the collection and dissemination of official statistics. As Argentina's public sector more generally, Indec features a mixed public service system in which merit and politicization co-exist for personnel decisions (cf. Echebarria \& Cortazar 2007). In the Department responsible for calculating the Consumer Price Index (CPI), for instance, only roughly a third of 114 public servants held permanent positions. The absence of tenure notwithstanding, higher echelons in the organization were frequently staffed with professionally qualified personnel (Ministerio Público de la Nación 2007a). With its professional staff, Indec's official statistics, including the consumer price index (CPI) and gross domestic product (GDP), followed standard international practices in their calculations and methodology; they were thus largely considered credible.

Starting in January 2007, the accuracy and coverage of statistics began to decline dramatically. As The Economist (2013) put it, "Since the government seized control of the statistics institute in 2007 the discrepancy between the official inflation number and that reported by independent economists has been up to 15 percentage points." "Blatantly inaccurate inflation statistics" were complemented by the distortion of other figures linked to inflation, including a possible overestimation of GDP growth by two percentage points per year (The Economist 2013). In 2014, the country, moreover, stopped publishing poverty rates altogether (El País 2015). The manipulation and non-disclosure of statistics led to formal IMF warnings to take "remedial measures" to report statistics according to IMF's rules. The country otherwise risked not being able to secure additional loans, or, at the extreme, being expelled from the IMF (IMF 2013).

The political rationale for statistical manipulation was, in practice, principally electoral. Officially, the government sought to curb official inflation rates to reduce foreign debt payments. According to one estimate, underestimating inflation rates saved the governments 
roughly US\$2.5bn in service payments of index-linked debt (The Economist 2013). At the same time, reports from a range of observers and the timing of the onset of politicization - the beginning of an electoral year at a time of a rapid rise in inflation - strongly point to an electoral motive: to distort public policy knowledge which could negatively affect the incumbent's electoral fortunes (see, among many, La Nación 2015).

In the case of Indec bureaucratic politicization contributed to the politicization of policy knowledge through the theorized mechanisms. A comparison of the unsuccessful government attempt to politicize Indec statistics without bureaucratic politicization in 2006 with the successful attempt at statistical politicization in 2007 with bureaucratic politicization substantiates this assertion.

Government attempts to politicize Indec statistics started in 2006. A high-level political appointee and long-time member of the governing Peronist Party with close links to President Kirchner - the Secretary of Commerce under the Minister of the Economy and Production repeatedly sought access to the list of entities which Indec surveyed to calculate inflation rates. The list was by law protected as a statistical secret to protect the neutrality of reporting entities and thus the integrity of their reports (Ministerio Público de la Nación 2007a). The Secretary of Commerce sought to undermine this integrity, seeking access to "visit these firms and look at the prices that you are disclosing” (Ministerio Público de la Nación 2007b, 2). Indec's highlevel bureaucrats, however, consistently refused to share the list, pointing to statistical secrecy and international statistical standards. In response, political requests, often accompanied by political intimidation, narrowed in on changes to the CPI methodology. Bureaucrats similarly rejected these, expressing their "concern with the danger of losing the CPI's credibility ... as well as the credibility of ... Indec.” (Ministerio Público de la Nación 2007a, 33). Via requests, channelled through the Minister of the Economy and Production, the Secretary of Commerce started imposing heavy, detailed and frequent CPI data reporting requirements on Indec over the subsequent months. While responding to them, bureaucrats were careful not to heed disaggregated data requests which could have undermined confidentiality.

In short, professional bureaucrats protected the integrity of public policy knowledge even in the face of strong political pressure to permit manipulation. As hypothesized, technical capacity to maintain international standards, a concern with the credibility of their agency and a commitment to reliable statistics all added to the incentives and ability of Indec's professional bureaucrats to resist the politicization of statistics. At one point in an effort to 
discredit Indec's own experts, the government even accused Indec officials of colluding with creditors to increase interest payments through higher inflation indices, albeit without presenting any supporting evidence (La Nación 2015).

Politicians were thus unable to politicize official statistics without politicizing Indec's bureaucracy. Bureaucratic politicization, however, was not beyond political reach: Argentina's 'mixed' public service system provided the government with formal discretion over the bureaucracy.

Congruently, in early 2007, the Minister of the Economy and Production, first, asked for a ministerial appointee to join the technical committee on revisions to the Consumer Price Index (CPI), and then replaced the Director of the CPI Department in Indec with this appointee. The new Director tellingly proclaimed herself as the "minister's delegate" (Clarin, 2007). In close succession, other high- and mid-level personnel in key positions - including several other departmental directors and the Director of Indec at-large - either resigned voluntarily or were “invited” to resign (Ministerio Público de la Nación 2007a, 3). They were replaced with loyal - and often non-professional - personnel. To illustrate, the new supervisor for the collection of consumer prices had previously been a body guard, most recently of the newly appointed CPI Director. The political appointees quickly moved to distort the method for calculating the CPI and to share the list of firms surveyed in the CPI with political authorities. Distortions in the CPI calculation were blatant. To cite one example: new "ceilings" in the IT system to calculate the CPI precluded price increases beyond certain levels - independent of whether or not these occurred in practice (La Nación 2015; Ministerio Público de la Nación 2007a).

Part of the remaining professional bureaucrats resisted statistical manipulations. A minority union of public servants in Indec (ATE-INDEC) publicly protested against it, for instance ( $\mathrm{La}$ Nación, 2015). This bureaucratic 'whistle-blowing' raised the government's reputational costs of politicizing government statistics. Bureaucrats also resisted statistical manipulation inside Indec. Mid-level bureaucrats frequently rejected requests to arbitrarily alter data collection or indicator calculation methods on technical grounds (Ministerio Público de la Nación 2007a). With bureaucratic politicization, their ability to do so was limited, however. Public protests were met with violence from the governing party union. Resistance inside Indec in turn was reportedly dealt with by redundancies, early retirements and transfers to positions without functions. Cooperation with requests for statistical manipulation, by contrast, could be rewarded with salary increases and promotions (La Nación 2015). 
In sum, professional bureaucrats resisted the politicization of official statistics by refusing to cooperate in its production and by alerting the public as whistle-blowers. Congruent with the theorized causal mechanisms, technical capacity, a concern with the reputation of their agency and a commitment to quality statistics all contributed to bureaucratic incentives and ability to resist politicizing policy knowledge. Once political actors politicized appointments, promotions and tenure in Indec's bureaucracy, however, bureaucratic incentives and ability changed. Career incentives to maintain and advance employment, low technical capacity and loyalty to appointing politicians all tilted bureaucratic incentives and ability towards the production of biased policy knowledge.

Bureaucratic politicization thus contributed to the politicization of policy knowledge in the case of the Argentinian statistics agency through the theorized mechanisms. Evidence for the theory's mechanisms and explanatory power in a single case could thus be established. Whether the argument is valid also more generally, however, requires a large-n analysis. Argentina's politicization was, arguably, particularly blatant. Moreover, our argument is not circumscribed to statistics agencies. ${ }^{5}$ Instead, recall that we argued more generally that, with bureaucratic politicization, policy knowledge is more likely to be produced or suppressed by government institutions in a way that favors incumbent performance and especially so in democracies.

The next section thus draws on large-n data to assess the broader validity of this theorized causal effect.

\section{Statistical Analysis}

In this section, we use time-series cross-section analysis to investigate the relationship between bureaucratic politicization and reliable policy knowledge on a large sample of countries over time. Apart from providing evidence for a large-n causal effect of our argument,

\footnotetext{
${ }^{5}$ Anecdotally, we could well expect the theoretical argument to travel beyond Argentina: bureaucratic politicization and politicized policy knowledge do coincide in countries as remote from Argentina as Greece (Sotiropoulos, 2004).
} 
this analysis allows us to test whether the relationship differs between democracies and autocracies. As noted, we expect the association to be stronger in democracies.

\section{Operationalization and measurement: policy knowledge and bureaucratic politicization}

As outlined in the introduction, governments are often the principal provider of information about policy and socio-economic conditions. Third-party provision or verification of such information is, given its cost and lack of access to governmental documents, frequently limited. To operationalize unbiased policy knowledge production by governments, our dependent variable, we thus rely on a measure of the degree to which national statistical offices collect - from other government institutions or by themselves - and disclose in an unbiased and reliable manner the 240 indicators included in the World Development Indicators (WDI) (Hollyer et al. 2014). ${ }^{6}$ While this measure was developed by Hollyer et al. (2014) as a proxy for government transparency, it arguably approximates our definition of (politicized) policy knowledge even better. Congruent with our concept of politicized policy knowledge, the measure (henceforth policy data) captures biases stemming from both the suppression and distortion of key policy knowledge captured by the range of WDI indicators, as inclusion in the WDIs of these statistics is conditional upon a World Bank quality control assessment of their reliability and unbiasedness. The measure is available for 125 countries from 1980 to 2010, allowing for analyses of the effects of bureaucratic politicization on policy knowledge over time and for a wide range of countries. ${ }^{7}$

The study of bureaucratic politicization - our main independent variable - has long suffered from a dearth of cross-time and cross-country data (see Rauch and Evans, 1999). With this in mind, we employ measures from two recent expert surveys. The first measure - which has a broad coverage in terms of countries and years included - asks experts to assess the extent to which the public administration is characterized by impartiality, and functions as a proxy measure of our dependent variable and is the one we use in the statistical analyses. The second measure - which has stronger construct validity for our purpose but poorer coverage - asks public administration experts to assess how important political connections are for civil servants' recruitment. This measure is used to validate the proxy measure.

\footnotetext{
${ }^{6}$ The indicator is a latent term predicting the presence or absence of data on the 240 WDI measures.

${ }^{7}$ On average, democracies score 2.46 while autocracies score 0.01 (higher values connotes less biased data).
} 
The measure used in the statistical analyses comes from the Varieties of Democracy (V-Dem) project's expert coding, which is based on estimates from over 2,500 country experts on 173 countries from 1900 to 2012 (Coppedge et al., 2016). Expert surveys have their limitations, not least in terms of calibration of responses from different experts. However, the V-Dem data collection effort is exceptional in its methodological safeguards and uses an innovative approach to deal with the problem of inter-coder reliability. The indicator used here is coded on a scale from 0 to 5 but is transformed to an interval-level estimate using Bayesian item response theory (IRT) modeling techniques which build on inter-coding reliability tests (see Coppedge et al. 2015; Pemstein et al. 2015). The V-Dem data also ensures a strong sample of experts: at least five experts with long-term in-country expertise and high levels of educational attainment provide estimates for each country-year indicator. Confidence in the validity of the expert estimates is thus enhanced.

Empirically, impartiality is a close proxy for (lack of) bureaucratic politicization: the $2014 \mathrm{~V}$ Dem measure is strongly and significantly $(\mathrm{r}=-0.76)$ negatively correlated with the second and more direct measure of bureaucratic politicization from a global survey of public administration experts carried out by the Quality of Government Institute (QoG) (Dahlström et al. 2015). ${ }^{8}$ Theoretically, this substantively strong correlation is not surprising: impartiality in the fulfillment of duties and merit career civil services are twin features of Weberian bureaucracies (Dahlström and Lapuente, forthcoming). Unfortunately, time-series data is not available for this more direct measure of bureaucratic politicization, which precludes its use in the panel data analyses below. However, the resulting empirical expectation of concurrence together with the significant cross-sectional correlation enhance confidence in the validity of bureaucratic impartiality as a proxy measure for bureaucratic politicization.

\section{Control variables}

To avoid spurious inferences, several control variables are included in the analyses. First, to ensure that our results are not a product of countries' financial or human capital, the models control for (logged) GDP per capita (Gleditsch, 2002) and education, measured as gross enrolment ratio in primary education for both sexes (from UNESCO). Apart from being an

\footnotetext{
${ }^{8}$ The 2014 Quality of Government Expert Survey covers 159 countries. Bureaucratic politicization is measured by the survey question: 'How often would you say the following occurs today? When recruiting public sector employees, the political connections of the applicants decide who gets the job.'
} 
indicator of human capital, which may affect the supply of qualified candidates for entry into civil service, an educated public is also more likely to demand information from government.

Since both administrative reform and the release of statistics sometimes may stem from donor demands, dependency on foreign aid could impact on the relationship between bureaucratic politicization and policy knowledge. Net official development assistance as a share of GDP (World Bank, 2013) is therefore also included as a control. Similarly, since involvement in international trade could strongly incentivize the production of high quality economic statistics, we control for trade, measured as the sum of exports and imports of goods and services as a share of GDP (UN statistics 2015). To account for government incentives to conceal data about (large) rents, we also control for oil rents, measured as net oil exports value per capita (Ross and Mahdavi 2015).

Moreover, to capture pressure on incumbents by political opponents or the media to provide unbiased policy knowledge, we control for unfree press and political competition. To control for unfree press we use an index from Freedom House. The index is computed by adding four component ratings: Laws and regulations, Political pressures and controls, Economic Influences and Repressive actions. The scale ranges from 0 (most free) to 100 (least free) (Freedom House, 2015). Executive Electoral Competitiveness (from the World Bank Database of Political Institutions) is measured on a 7-point scale where higher scores reflect more political competition (Beck et al. 2001).

Political competition has been identified as a potential driving force behind both the independent and dependent variables used here. Geddes (1994) posits that political competition may induce politicians to strengthen bureaucratic autonomy in order to limit the power of successive incumbents (see also Keefer 2007). Building on similar reasoning, recent work on government transparency attributes governments' willingness to release data on political competition (Berliner 2014; Berliner and Erlich 2015). Including a measure of political competition therefore reduces the risk that any association between impartial bureaucracy and policy data is merely a function of omitted variable bias.

To distinguish between democracies and autocracies we use the Boix-Miller-Rosato dichotomous classification of democracy, according to which countries are defined as democracies if they feature political leaders chosen through free and fair elections and satisfy a threshold value of suffrage (Boix, Miller and Rosato 2013). In the analysis, this measure is inverted so that 1 stands for autocracy and 0 for democracy. Data for all the control variables 
were taken from the Quality of Government Institute's Standard Dataset (Teorell et al. 2013; 2016). The time period included is 1980-2010 and the number of countries is between 117 and 121 depending on availability of data. ${ }^{9}$

\section{Results}

We estimate the effect of bureaucratic politicization on policy knowledge with fixed effects (FE) cross-sectional time-series regression linear models ${ }^{10}$ and with system GMM (generalized method of moments) models (Arrellano-Bover/Blundell-Bond estimator). In line with the hypothesis of a detrimental effect of bureaucratic politicization on policy data, our proxy measure for the inverse of politicization - impartial bureaucracy - is positively and significantly related to the publication of reliable policy data. Importantly, the effect is significant only in democracies. In other words, in democratic countries bureaucratic politicization is negatively associated with government publications of credible policy-related statistics.

Table 1 reports the results for the full sample (including both authoritarian regimes and democracies). Models 1-3 shows the results for the FE estimation and the full sample but with different sets of variables. The first model is a simple bivariate analysis, which shows that the effect of impartial bureaucracy is significant and positively related to reliable publication of policy data in the full sample. Models 2 and 3 introduce more controls. Model 2 controls only for economic variables and education while model 3 also includes controls related to the quality of democracy in a country. In these models impartial bureaucracy is positively and significantly related to the release of reliable policy data for the full sample.

Consistent results across the models lend credence to a significant relationship between impartial bureaucracy and the publication of government statistics. With our data, we can also assess an important empirical implication of the theory. As outlined above, we expect the relationship to be much stronger in democracies, where meaningful elections take place on a regular basis. To this end we introduce an interaction term with impartial bureaucracy and autocracy (Table 1, models 4-6). The results in these models show that the effect of impartial

\footnotetext{
${ }^{9}$ Some of the control variables are available only for a shorter period. The control for unfree press is only available from 1993.

${ }^{10}$ Random effects offer greater efficiency than the FE models but, as the Hausman Test was rejected at the $1 \%$ level, FE provide for more consistent estimates. However, random effects models (generalized least squares estimator) yield similar results (not shown here but available from the authors upon request).
} 
bureaucracy is only statistically significant in democracies. This suggests that bureaucratic politicization is associated with cooking the books in democracies, but not in autocracies. Model 6 yields the same results but employs system GMM with a lagged dependent variable.

[Table 1 about here]

Figure 1 plots the relationship in democracies and autocracies respectively. As expected, the slope of the line for democracies is positive while the slope for authoritarian regimes is indistinguishable from zero. Moreover, the low predicted values for policy knowledge at low levels of bureaucratic impartiality (and thus high levels of politicization) in democracies suggests that refraining from politicization of the bureaucracy is important in democracies.

[Figure 1 about here]

To further look at the relationship and its implications in democracies, table 2 shows results from analyses in which we have only included democracies. We can see from the results that impartial bureaucracy is positively and significantly related to reliable publication of policy data both with the FE and GMM models and with different sets of controls. ${ }^{11}$.

[Table 2 about here]

\section{Conclusions and implications}

Public administration scholars have long since established that the structure of the state including personnel management - affects the functioning of democracy. Bureaucratic politicization, in particular, has been associated with public service delivery failures, corruption and clientelist electoral strategies. This paper argues and shows that the politicization of the bureaucracy has an additional, quite profound consequence for democracies. A politicized bureaucracy contributes to the politicization of policy knowledge published by governments. The case of Argentina suggests that politicization of the statistics bureau enabled the Kirchner administration to doctor economic indicators, which - at least in terms of the data presented - put the government in a better light ahead of an election. This suggests that tweaking statistics to exaggerate accomplishments for electoral reasons may in

\footnotetext{
11 The effects are similar with random effects (not shown here but available from the authors upon request.).
} 
some cases not only be an opportunity resulting from political control of the bureaucracy, but even one of the reasons for such politicization in the first place. The time-series cross-sectional analyses confirm the association across polities and over time, but only in democratic regimes. Democracies with a less impartial, and thus presumably more politicized, bureaucracy were found to be more likely to suppress or bias data about the economic and societal state of affairs in the country. The mixed methods evidence thus presents a compelling case that bureaucratic politicization contributes to variations in the extent to which democracies compile and make publicly available reliable knowledge about policy, the economy and society.

The implications of these results for the functioning of democracies, and the vast scholarship on the political economy of elections (e.g. Przeworski, Stokes and Manin 1999), are substantial and two-fold. First, distorted and suppressed policy knowledge is likely to add to the prevalent public goods underperformance of democratic systems with politicized bureaucracies. Formulating evidence-based policies is difficult under any circumstances but amounts to mere guesswork when relevant, context-specific knowledge is lacking. Even wellintentioned policy makers and bureaucrats will be ill-equipped under such circumstances. Second, the manipulation of policy knowledge in democracies may also undermine both retrospective and prospective voting, as incumbents and challengers alike have greater leeway in making claims about societal conditions. Policy knowledge injects realism into electoral campaigns, and when absent or lacking, the electorate must base vote-choices on other cues.

The findings thus add to our understanding of how the structure and organization of the state, and in particular the political control over bureaucratic careers, affect politics, policy formation and policy implementation. That a separation of executive, legislative and judicial powers benefits accountability is a well-established precept in state-building and constitutional thinking. While insights on the importance of separation between the political and administrative spheres of government also have historical roots (Weber 1978 [1921]; Wilson 1887), this paper contributes to the growing appreciation of the benefits of institutional safeguards that keep politics from excessively infusing state organizations and, in particular, bureaucratic careers (Cornell and Grimes 2015a, b; Dahlström and Lapuente forthcoming; Geddes 1994; Gingerich 2013; Robinson \& Verdier 2013; Nistotskaya and Cingolani, 2015; Shefter 1994).

Institutional arrangements that allow popularly elected representatives extensive control over the bureaucracy can, of course, enhance democratic accountability. Moreover, the presence of 
opposition parties and greater press freedom, among many other factors, could be expected to provide crucial checks on governments, including in regards to its ability to bias policy knowledge. Yet, as our paper - and others - have shown, electoral logics in new democracies in particular can induce politicians to extend their mandate in ways that undermine the very institutions necessary to sustain the quality of democracy in the first place - including by depriving the electorate of the data to judge government performance. In this sense, the theoretical arguments and empirical findings advanced in this piece are also consistent with and contribute to debates on institutional sequencing and democratization (e.g., Mansfield and Snyder 2005). 


\section{References}

Aucoin, P. 2012. "New Political Governance in Westminster Systems: Impartial Public Administration and Management Performance at Risk." Governance. 25(2), p. 177-199

Beck, T., Clarke, G., Groff, A., Keefer, P., \& Walsh, P. 2001. "New tools in comparative political economy: The database of political institutions." The World Bank Economic Review, 15 (1), 165176.

Berliner, D. 2014. The Political Origins of Transparency. Journal of Politics. 76(2):479-491.

Berliner, D. and Aaron Erlich. 2015. Competing for Transparency: Political Competition and Institutional Reform in Mexican States. American Political Science Review. 109(1):110-128.

Bersch, K., Praça, S. and Taylor, M. 2016. "State Capacity, Bureaucratic Politicization, and Corruption in the Brazilian State, Governance, Early View

Boix, C., M Miller and S. Rosato 2013. "A complete data set of political regimes, 1800-2007." Comparative Political Studies, Vol. 46, No. 12, p. 1523-1554

Boston, J. \& J.R. Nethercote. 2012. "Reflections on "New Political Governance in Westminster Systems." Governance, Vol. 25(2), p. 201-205

Cingolani, L., Thomsson, K., \& de Crombrugghe, D. 2015. "Minding Weber more than ever? The impacts of State Capacity and Bureaucratic Autonomy on development goals." World Development, Vol. 72, p. 191-207

Clarin, 2007. Duro comunicado de los trabajadores del INDEC contra el relevo de la encargada de medir los precios. Retrieved May 8, 2015 from http://edant.clarin.com/diario/2007/02/01/um/m01355726.htm

Coppedge, Michael, John Gerring, Staffan I. Lindberg, Daniel Pemstein, Svend-Erik Skaaning, Jan Teorell, Eitan Tzelgov, Yi-ting Wang, David Altman, Michael Bernhard, M. Steven Fish, Adam Glynn, Allen Hicken, Carl Henrik Knutsen, Kelly McMann, Megan Reif, Jeffrey Staton, Brigitte Zimmerman. 2016. Varieties of Democracy: Methodology v5. Varieties of Democracy (V-Dem) Project.

Coppedge, Michael, John Gerring, Staffan I. Lindberg, Svend-Erik Skaaning, Jan Teorell, with David Altman, Michael Bernhard, M. Steven Fish, Adam Glynn, Allen Hicken, Carl Henrik Knutsen, Kelly McMann, Pamela Paxton, Daniel Pemstein, Jeffrey Staton, Brigitte Zimmerman, Frida Andersson, Valeriya Mechkova, and Farhad Miri. 2015. "V-Dem Codebook v5." Varieties of Democracy (V-Dem) Project.

Cornell, A. 2014. "Why Bureaucratic Stability Matters for the Implementation of Democratic Governance Programs." Governance 27(2): 191-214.

Cornell, Agnes, and Marcia Grimes. 2015a. "Institutions as Incentives for Civic Action: Bureaucratic Structures, Civil Society, and Disruptive Protests." The Journal of Politics. 77(3): 664-678.

Cornell, Agnes and Marcia Grimes, 2015b. "Political Control of Bureaucracies as an Incentive for Party Behavior." In Carl Dahlström and Lena Wängnerud (eds) Elites, Institutions and the Quality of Government. Basingstoke: Palgrave MacMillan.

Cornell, Agnes, and Victor Lapuente. 2014. "Meritocratic Administration and Democratic Stability." Democratization 21(7): 1286-304.

Dahlström, C. and V. Lapuente (forthcoming). Organizing Leviathan: How the relationship between politicians and bureaucrats shapes good government. Cambridge: Cambridge University Press.

Dahlström, C., V. Lapuente, and J. Teorell. 2012. "The Merit of Meritocratization." Political Research Quarterly 65(3): 656-68.

Dahlström, Carl, Jan Teorell, Stefan Dahlberg, Felix Hartmann, Annika Lindberg and Marina Nistotskaya. 2015. The QoG Expert Survey Dataset II. University of Gothenburg: The Quality of Government Institute.

Echebarria, K., \& Cortazar, J. 2007. 'Public Administration and Public Employment Reform In Latin America.' In E. Lora (Ed.), The State of State Reform in Latin America (pp. 123-155). Washington DC: Inter-American Development Bank.

Eckstein, H. (1975). Case studies and theory in political science. In F. I. Greenstein \& N. W. Polsby (Eds.), Handbook of political science. Political science: Scope and theory (Vol. 7, pp. 94-137). Reading, MA: Addison-Wesley 
El País. 2015. Argentina deja de contar pobres. Retrieved May 8, 2015 from http://internacional.elpais.com/internacional/2015/03/27/actualidad/1427490866_101379.html

Evans, Peter and James Rauch. 1999. "Bureaucracy and Growth: A Cross-National Analysis of the Effects of 'Weberian' State Structure on Economic Growth." American Sociological Review 64(5),748-765.

Freedom House. 2015. Freedom in the world: Aggregate and subcategory scores. Retrieved from https://freedomhouse.org/report/freedom-world-aggregate-and-subcategory-scores

Gailmard, Sean and John W. Patty. 2009. "Slackers and Zealots: Civil Service, Policy Discretion, and Bureaucratic Expertise.” American Journal of Political Science. 51(4):873-889.

Gallo, N. and D. E. Lewis. 2011. "The Consequences of Presidential Patronage for Federal Agency Performance." Journal of Public Administration Research and Theory. 22:219-243.

Geddes, B. 1994. Politician's Dilemma: Building State Capacity in Latin America. Berkeley: University of California Press.

George, A. and Bennett, A. 2005. Case Studies and Theory Development in the Social Sciences. Cambridge, MA: MIT Press.

Gingerich, Daniel W. 2013. Political Institutions and Party-Directed Corruption in South America : Stealing for the Team. Cambridge: Cambridge University Press.

Gleditsch, K. S. 2002. "Expanded trade and gdp data." Journal of Conflict Resolution, 46 (5), 712 724.

Grube, D. 2014. "Responsibility to Be Enthusiastic? Public Servants and the Public Face of 'Promiscuous Partisanship'." Governance, 28(3), p. 305-320

Hollyer, James, Rosendorff, B. Peter and Vreeland, James. 2011. "Democracy and Transparency." Journal of Politics. Vol. 73(4), pp 1191-1205.

Hollyer, James, Rosendorff, B. Peter and Vreeland, James. 2014. "Measuring Transparency." Political Analysis. pp. 1-22 doi:10.1093/pan/mpu001

Hood, C. 2006. "Gaming in Targetworld: The Targets Approach to Managing British Public Services." Public Administration Review, Vol. 66(4), p. 515-521

Horn, M. J. 1995. The Political Economy of Public Administration: Institutional Choice in the Public Sector. Cambridge: Cambridge University Press.

IMF, 2013. Statement by the IMF Executive Board on Argentina. Retrieved May 9, 2015 from https://www.imf.org/external/np/sec/pr/2013/pr1333.htm

Jerven, Morten 2013. Poor Numbers. How We Are Misled by African Development Statistics and What to Do about It. Cornell University Press.

Keefer, P. 2007. "Clientelism, Credibility, and the Policy Choices of Young Democracies." American Journal of Political Science 51(4) :804-21.

Krätke, Florian and Byiers, Bruce. 2014. The Political Economy of Official Statistics - Implications for the Data Revolution in Sub-Saharan Africa. Discussion Paper No. 5, Paris: OECD PARIS21 Partnership in Statistics for Development in the 21st Century

Krause, G., Lewis, D. and Douglas, J. 2006. "Political Appointments, Civil Service Systems, and Bureaucratic Competence: Organizational Balancing and Executive Branch Revenue Forecasts in the American States." American Journal of Political Science, Vol. 50, No. 3, p. 770-787

La Nación, 2015. "El Indec, la máquina de la mentira." Retrieved May 9, 2015 from http://casos.lanacion.com.ar/indec-la-maquina-de-la-mentira

Lewis, D. E. 2007. “Testing Pendleton's Premise: Do Political Appointees Make Worse Bureaucrats?" Journal of Politics. 69(4):1073-1088.

Mansfield E.D. and J. Snyder. 2005. Electing to Fight: Why Emerging Democracies Go to War Cambridge: MIT Press, 2005.

Ministerio Público de la Nación, 2007a. Dictamen de Manuel Garrido. Fiscalía de Investigaciones Administrativas, Buenos Aires, 15 de mayo de 2007

Ministerio Público de la Nación, 2007b. Dictamen de Carlos E. Stornelli: Solicita Se Reciban $\begin{array}{lllll}\text { Declaraciones } & \text { Indagatorias. } & \text { Retrieved } & \text { May 9, } 2015 \text { from }\end{array}$ http://www.ateindec.org.ar\%2Fdocumentos\%2F2007-1200_Pedidos_indagatoria.pdf\&ei=6YJOVa3GHYTN7QaftIDIBg\&usg=AFQjCNEIDrkBGCANz TLhDNfuNDcCSz7XWg\&bvm=bv.92885102,d.bGg 
Mulgan, R. 2007. "Truth in Government and the Politicization of Public Service Advice." Public Administration, Vol. 85(3), p. 569-586.

Nistotskaya, Marina and Luciana Cingolani. 2015. "Bureaucratic Structure, Regulatory Quality, and Entrepreneurship in a Comparative Perspective: Cross-Sectional and Panel Data Evidence." Journal of Public Administration Research and Theory. doi:10.1093/jopart/muv026

Oliveros, V. 2013. A Working Machine: Patronage Jobs and Political Services in Argentina. (Ph.D.), Columbia University, New York.

Pemstein, D.; K. L. Marquardt, E. Tzelgov, Y.Wang, and F. Miri (2015). The V-Dem Measurement Model: Latent Variable Analysis for Cross-National and Cross-Temporal Expert-Coded Data. Varieties of Democracy Institute: Working Paper No. 21.

Przeworski, Adam Susan C. Stokes and Bernard Manin (eds). 1999. Democracy, Accountability and Representation. Cambridge : Cambridge University Press, 1999

Repo, A. J. 1989. "The value of information: Approaches in economics, accounting, and management science." Journal of the American Society for Information Science. 40: 68-85.

Robinson, J., \& Verdier, T. 2013. "The Political Economy of Clientelism." The Scandinavian Journal of Economics, 115(2), 260-291.

Ross, M., \& Mahdavi, P. (2015). Oil and gas data, 1932-2014. Harvard Dataverse.

Sandefur, Justin and Glassman, Amanda. 2014. The Political Economy of Bad Data: Evidence from African Survey \& Administrative Statistics. Working Paper 373. Washington DC: Center for Global Development

Schuster, C. 2016. When the Victor Cannot Claim the Spoils: Institutional Incentives for Professionalizing Patronage States. IDB Working Paper Series No IDB-WP-667, Washington DC: Inter-American Development Bank

Schuster, C. 2016a. What Causes Patronage Reform? It Depends on the Type of Civil Service Reform. Public Administration, Vol 94(4), p. 1094-1104

Serra, Gerardo. 2014. "An uneven statistical topography: the political economy of household budget surveys in late colonial Ghana, 1951-1957." Canadian Journal of Development Studies, 35 (1). pp. 9-27

Shefter, M. 1994. Political Parties and the State: The American Historical Experience. Princeton, NJ: Princeton University Press.

Sotiropoulos, D. (2004). Two faces of politicization of the civil service - The case of contemporary Greece. In G. Peters \& J. Pierre (Eds.), The Politicization of the Civil Service in Comparative Perspective (pp. 257-282). London: Routledge.

Stevens, Alex. 2011. "Telling Policy Stories: An Ethnographic Study of the Use of Evidence in Policymaking in the UK." Journal of Social Policy. 40(2): 237-255

Stokes, S., T. Dunning, M. Nazareno, and V. Brusco. 2013. Brokers, Voters, and Clientelism: The Puzzle of Distributive Politics. Cambridge: Cambridge University Press.

Stone, Deborah. 2012. Policy Paradox - The Art of Political Decision-Making. New York: W.W. Norton \& Company

Stone, Diane. 2012. 'Agents of Knowledge.' In David Levi-Faur (Ed.) The Oxford Handbook of Governance. Oxford: Oxford University Press, p. 339-351

Teorell, J., N. Charron, S. Dahlberg, S. Holmberg, B. Rothstein, P. Sundin and R. Svensson. 2013. The Quality of Government Dataset, version 20Dec13. The Quality of Government Institute, University of Gothenburg. http://www.qog.pol.gu.se/data/datadownloads/qogstandarddata/.

Teorell, J., S. Dahlberg, Sören Holmberg, Bo Rothstein, Anna Khomenko \& Richard Svensson. 2016. The Quality of Government Standard Dataset, version Jan16. University of Gothenburg: The Quality of Government Institute, http://www.qog.pol.gu.se doi:10.18157/QoGStdJan16

The Economist, 2013. The IMF and Argentina - Motion of censure. Retrieved May 8, 2015 from http://www.economist.com/news/americas/21571434-fund-blows-whistle-motion-censure

UN Statistics. (2015). National accounts main aggregates database. Retrieved from http://unstats.un.org/unsd/snaama/dnlList.asp

van Kerkhoff,'L. and L. Lebel. 2006. "Linking Knowledge and Action for Sustainable Development." Annual Review of Environment and Resources. Vol. 31: 445-477

Weber, M. 1978 [1921]. Economy and Society, Roth, G. and Wittich, C. (eds). Berkeley: University of California Press. 
Wildavsky, A. 1979. The Art and Craft of Policy Analysis. London and Basingstoke: The Macmillan Press.

Williams, A., 2010. 'Is Evidence-Based Policy Making Really Possible? Reflections for Policymakers and Academics on Making Use of Research in the Work of Policy.' In Hal Colebatch, Robert Hoppe, \& Mirko Noordegraaf, eds. Working for Policy. Amsterdam: Amsterdam Univ Press, p. 195-210.

Wilson, W. 1887. “A Study of Administration.” Political Science Quarterly 2(2): 197-222.

Wood, B. Dan, and Richard W. Waterman. 1991. "The Dynamics of Political Control of the Bureaucracy." American Political Science Review 85(3): 801-28.

World Bank 2013. World Development Indicators. Washington DC: The World Bank Group, Published Online, January 24, 2013.

World Bank, 2014. Statistical Capacity Indicators. Retrieved May 7, 2015 from http://databank.worldbank.org/Data/Views/VariableSelection/SelectVariables.aspx? source=Statisticalcapacity-indicators

Yin, R. 2013. Case Study Research: Design and Methods. Sage Publishing 
Figures and Tables

Figure 1. The relationship between impartial bureaucracy and policy data in democracies and autocracies

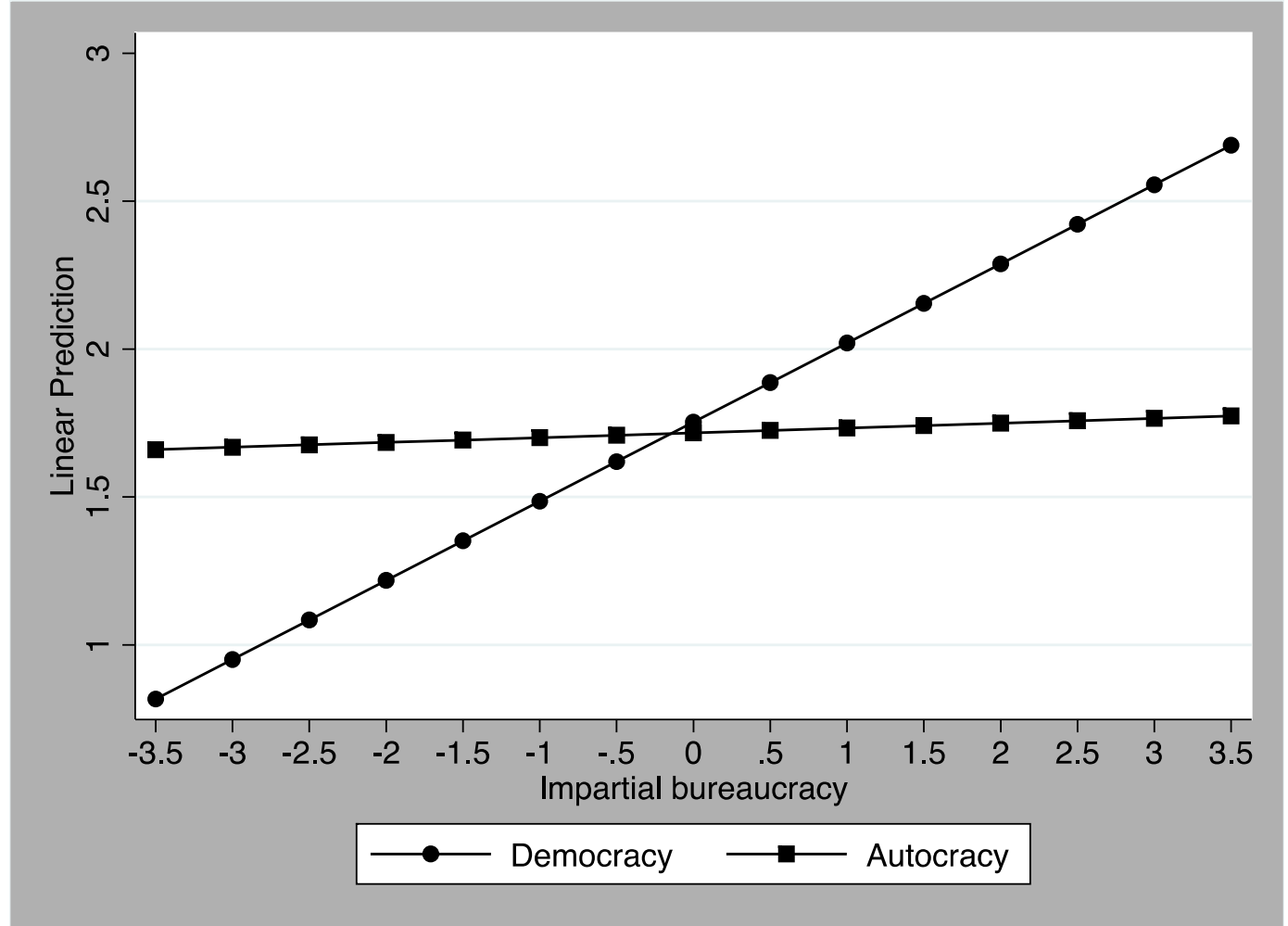

Note: The figure is based on Table 1, model 5. 
Table 1. Impartial bureaucracy and policy data (full sample)

\begin{tabular}{|c|c|c|c|c|c|c|}
\hline \\
\hline & (1) & $(2)$ & (3) & (4) & $(5)$ & (6) \\
\hline & $(\mathrm{FE})$ & $(\mathrm{FE})$ & $(\mathrm{FE})$ & $\begin{array}{c}\text { (FE) } \\
\text { Ref. } \\
\text { category } \\
\text { democracy }\end{array}$ & $\begin{array}{c}\text { (FE) } \\
\text { Ref. } \\
\text { category } \\
\text { democracy }\end{array}$ & $\begin{array}{c}\text { (GMM) } \\
\text { Ref. } \\
\text { category } \\
\text { democracy }\end{array}$ \\
\hline $\begin{array}{l}\text { Impartial } \\
\text { bureaucracy }\end{array}$ & $0.0473^{*}$ & $0.0906^{* *}$ & $0.138^{* *}$ & $0.160^{* * * *}$ & $0.267^{* * *}$ & $0.648^{* *}$ \\
\hline & $(0.0282)$ & $(0.0394)$ & $(0.0659)$ & $(0.0548)$ & $(0.0849)$ & $(0.296)$ \\
\hline Policy data $(\mathrm{t}-1)$ & & & & & & $1.112^{* * * *}$ \\
\hline & & & & & & $(0.0518)$ \\
\hline Autocracy & & & & -0.00132 & -0.0360 & 0.217 \\
\hline & & & & $(0.0569)$ & $(0.0815)$ & $(0.247)$ \\
\hline $\begin{array}{l}\text { Impartial } \\
\text { bureaucracy* } \\
\text { Autocracy }\end{array}$ & & & & $-0.111^{*}$ & $-0.251^{* *}$ & $-0.542^{*}$ \\
\hline & & & & $(0.0593)$ & $(0.104)$ & $(0.300)$ \\
\hline Ln(GDP/capita) & & $0.137^{*}$ & 0.0783 & $0.135^{*}$ & 0.0708 & $-0.537^{* * *}$ \\
\hline & & $(0.0749)$ & $(0.0812)$ & $(0.0744)$ & $(0.0810)$ & $(0.184)$ \\
\hline Education & & 0.00196 & 0.00166 & 0.00194 & 0.00145 & -0.00208 \\
\hline & & $(0.00212)$ & $(0.00286)$ & $(0.00212)$ & $(0.00287)$ & $(0.00517)$ \\
\hline ODA/GDP & & $-2.84 \mathrm{e}-09$ & $-2.10 \mathrm{e}-09$ & $-2.84 \mathrm{e}-09$ & $-2.01 \mathrm{e}-09$ & $-4.17 \mathrm{e}-09$ \\
\hline & & $(4.22 \mathrm{e}-09)$ & $(4.89 \mathrm{e}-09)$ & $(4.22 \mathrm{e}-09)$ & $(4.88 \mathrm{e}-09)$ & $(3.16 \mathrm{e}-08)$ \\
\hline Trade/GDP & & $0.00194^{* *}$ & 0.00116 & $0.00205^{* *}$ & 0.00127 & $-0.0108^{* *}$ \\
\hline & & $(0.000952)$ & $(0.00136)$ & $(0.000954)$ & $(0.00136)$ & $(0.00532)$ \\
\hline $\begin{array}{l}\text { Oil rents per } \\
\text { capita }\end{array}$ & & -0.0000418 & -0.0000587 & -0.0000427 & -0.0000618 & 0.000161 \\
\hline & & $(0.0000458)$ & $(0.0000527)$ & $(0.0000458)$ & $(0.0000526)$ & $(0.000236)$ \\
\hline Unfree press & & & -0.00261 & & -0.00221 & -0.00355 \\
\hline & & & $(0.00264)$ & & $(0.00266)$ & $(0.00869)$ \\
\hline $\begin{array}{l}\text { Political } \\
\text { Competition }\end{array}$ & & & 0.00193 & & 0.00554 & 0.0453 \\
\hline & & & $(0.0144)$ & & $(0.0145)$ & $(0.0413)$ \\
\hline Constant & $1.798^{* * *}$ & $0.415^{* * *}$ & $1.071^{* * *}$ & $0.343^{* * *}$ & $0.997^{* * *}$ & $4.513^{* * *}$ \\
\hline & $(0.00651)$ & $(0.0428)$ & $(0.0797)$ & $(0.0431)$ & $(0.0798)$ & $(1.325)$ \\
\hline $\begin{array}{l}\text { Nobservations } \\
\text { (country years) }\end{array}$ & 3618 & 2500 & 1707 & 2500 & 1707 & 1825 \\
\hline$N$ countries & 121 & 118 & 117 & 118 & 117 & 118 \\
\hline$R^{2}$ & 0.32 & 0.45 & 0.45 & 0.44 & 0.44 & \\
\hline $\begin{array}{l}\text { Number of } \\
\text { instruments }\end{array}$ & & & & & & 48 \\
\hline $\begin{array}{l}\text { Hansen J-test( } \\
\text { p-value) }\end{array}$ & & & & & & 0.128 \\
\hline
\end{tabular}

Note: Standard errors in parentheses. ${ }^{*} p<0.10,{ }^{* *} p<0.05,{ }^{* * *} p<0.01$. 
Table 2. Impartial bureaucracy and policy data in democracies

\begin{tabular}{|c|c|c|c|c|}
\hline & (1) & (2) & (3) & (4) \\
\hline & $\mathrm{FE}$ & $\mathrm{FE}$ & GMM & GMM \\
\hline \multirow[t]{2}{*}{$\begin{array}{l}\text { Impartial } \\
\text { bureaucracy }\end{array}$} & $0.268^{* * *}$ & $0.386^{* * *}$ & $1.178^{* * *}$ & $0.730^{*}$ \\
\hline & $(0.0929)$ & $(0.123)$ & $(0.404)$ & $(0.397)$ \\
\hline \multirow[t]{2}{*}{ Policy data(t-1) } & & & $1.076^{* * *}$ & $1.170^{* * * *}$ \\
\hline & & & $(0.0744)$ & $(0.0736)$ \\
\hline \multirow[t]{2}{*}{ Ln(GDP/capita) } & $0.281^{* *}$ & 0.0939 & $-1.020^{* *}$ & -0.621 \\
\hline & $(0.112)$ & $(0.125)$ & $(0.428)$ & $(0.399)$ \\
\hline \multirow[t]{2}{*}{ Education } & 0.00466 & 0.00605 & -0.0172 & -0.0178 \\
\hline & $(0.00468)$ & $(0.00571)$ & $(0.0173)$ & $(0.0227)$ \\
\hline \multirow[t]{2}{*}{ ODA/GDP } & $-2.57 e-09$ & $-3.01 \mathrm{e}-09$ & $-3.76 e-08$ & $2.67 \mathrm{e}-08$ \\
\hline & $(5.94 \mathrm{e}-09)$ & $(6.60 \mathrm{e}-09)$ & $(9.08 \mathrm{e}-08)$ & $(4.63 e-08)$ \\
\hline \multirow[t]{2}{*}{ Trade/GDP } & $0.00336^{*}$ & 0.00384 & -0.0140 & $-0.0244^{* *}$ \\
\hline & $(0.00189)$ & $(0.00256)$ & $(0.00979)$ & $(0.0102)$ \\
\hline \multirow[t]{2}{*}{$\begin{array}{l}\text { Oil rents per } \\
\text { capita }\end{array}$} & -0.0000714 & -0.000101 & -0.0000437 & -0.0000603 \\
\hline & $(0.0000703)$ & $(0.0000799)$ & $(0.0000910)$ & $(0.000101)$ \\
\hline \multirow[t]{2}{*}{ Unfree press } & & -0.00550 & & -0.00762 \\
\hline & & $(0.00477)$ & & $(0.0170)$ \\
\hline \multirow[t]{2}{*}{$\begin{array}{l}\text { Political } \\
\text { Competition }\end{array}$} & & -0.0592 & & -0.0388 \\
\hline & & $(0.0520)$ & & $(0.121)$ \\
\hline \multirow[t]{2}{*}{ Constant } & $-0.629^{* * * *}$ & $1.251^{\text {**** }}$ & $9.903^{* *}$ & $7.961^{* *}$ \\
\hline & $(0.0786)$ & $(0.123)$ & $(3.849)$ & $(3.787)$ \\
\hline $\begin{array}{l}N \text { observations } \\
\text { (country years) }\end{array}$ & 1396 & 1022 & 1475 & 1101 \\
\hline$N$ countries & 79 & 78 & 80 & 79 \\
\hline$R^{2}$ & 0.31 & 0.27 & & \\
\hline $\begin{array}{l}\text { Number of } \\
\text { instruments }\end{array}$ & & & 28 & 38 \\
\hline $\begin{array}{l}\text { Hansen J-test } \\
\text { (p-value) }\end{array}$ & & & 0.102 & 0.109 \\
\hline
\end{tabular}

Note: Standard errors in parentheses. ${ }^{*} p<0.10,{ }^{* *} p<0.05,{ }^{* * *} p<0.01$. 